\title{
Development of a Real-Time RT-PCR for the Universal Detection of LChV1 and Study of the Seasonal Fluctuation of the Viral Titer in Sweet Cherry Cultivars
}

Asimina T. Katsiani and Polyxeni Pappi, Plant Pathology Laboratory, Faculty of Agriculture, Forestry and Natural Environment, School of Agriculture, Aristotle University of Thessaloniki, 54124 Thessaloniki, Greece; Antonio Olmos, Instituto Valenciano de Investigaciones Agrarias, 46113 Moncada, Valencia, Spain; and Konstantinos E. Efthimiou, Varvara I. Maliogka, ${ }^{\dagger}$ and Nikolaos I. Katis, Plant Pathology Laboratory, Faculty of Agriculture, Forestry and Natural Environment, School of Agriculture, Aristotle University of Thessaloniki

\begin{abstract}
Little cherry virus 1 (LChV1) is a sweet cherry pathogen which has lately been reported in other Prunus spp. LChV1 variability makes reliable detection a challenging undertaking. The objective of this work was to develop a rapid, sensitive, and reliable one-tube, real-time reversetranscription polymerase chain reaction (RT-PCR) for the detection and quantification of LChV1. Primers and a TaqMan probe were designed, using conserved regions of the capsid protein gene. Detection range was evaluated using several divergent viral isolates. The amplification efficiency

of the method was estimated at $96.7 \%$, whereas the detection limit was about 100 RNA copies. The protocol was applied in the study of virus fluctuation within leaves and phloem tissue throughout the year and the best periods to test and plant tissues to sample were determined. Comparative analysis of this method with a previously published nested RT-PCR revealed the higher analytical and diagnostic sensitivity of the new test, making it a reliable tool that can be used in routine testing and certification programs.
\end{abstract}

Little cherry virus 1 (LChV1) is a member of the genus Velarivirus (family Closteroviridae), with hosts primarily belonging to the family Rosaceae (Barba et al. 2015). LChV1 is considered latent; however, some isolates have been associated with various disorders (Candresse et al. 2013; Matic et al. 2009; Wang et al. 2016), with the number of virus reports worldwide increasing (Candresse et al. 2013; Jelkmann and Eastwell 2011; Lim et al. 2015; Matic et al. 2009; Ruiz-García et al. 2016; Wang et al. 2016). Recent surveys in Greece determined that LChV1 is widespread in sweet cherry orchards and rather rare in plum and peach, with phylogenetic analysis revealing a highly variable virus population (Katsiani et al. 2015). LChV1 detection is currently based on reverse-transcription polymerase chain reaction (RT-PCR) assays. The existing real-time and conventional RT-PCR (Jelkmann et al. 2008) failed in the detection of most of the Greek and Spanish isolates (Katsiani et al. 2015; RuizGarcía et al. 2016). Given the facts, we developed a real-time RTPCR assay for the universal detection of LChV1, which was used to determine the best time and tissue for sampling. The new assay will be a valuable tool for certification schemes and routine testing.

\section{Materials and Methods}

Plant material and virus sources. Eleven Greek isolates from sweet cherry, peach, and plum (Katsiani et al. 2015), as well as isolates from Poland (XX1/1 and W7:30 duz), Italy (ITMAR and ITSPA),

Current address Polyxeni Pappi: Laboratory of Plant Virology, Department of Viticulture, Vegetable Crops, Floriculture and Plant Protection, Institute of Olive Tree, Subtropical Crops and Viticulture, National Agricultural Research Foundation, Hellenic Agricultural Organization-DEMETER, Heraklion, Greece.

${ }^{\dagger}$ Corresponding author: V. Maliogka; E-mail: vmaliogk@agro.auth.gr

Funding: This research has been co-financed by the European Union (European Social Fund) and Greek National Funds through the Operational Program "Education and Lifelong Learning" of the National Strategic Reference Framework Research Funding Program: Heracleitus II: Investing in Knowledge Society through the European Social Fund.

*The $\boldsymbol{e}$-Xtra logo stands for "electronic extra" and indicates that two supplementary tables are published online.

Accepted for publication 19 November 2017.

(c) 2018 The American Phytopathological Society
Germany (GER), and Canada (CAN), were used in this study. Primer design was based on available sequences deposited in GenBank: ITMAR (EU715989), ITSPA (EU715996), V2356 (JX669615), UW2 (Y10237) GR (HG792420),G15 3 (LN794218), Ponferrada (KX192367), and Jerte (KX192366).

The fluctuation of LChV1 titer throughout the year was monitored using samples from infected, asymptomatic, sweet cherry cultivars Burlat and Tragana Edessis, which were collected monthly in 2013. Dormant cuttings collected from infected plants were grafted onto healthy rootstocks and maintained since 2010. RT-PCR tests and sequencing indicated that the Tragana Edessis plants were singly infected with the G55 3, G15 3, and G49 2 isolates, whereas the Burlat plants carried single infections with the G24 3, PHLC29 3, G18 2, PHLC28 5 , and PHLC17 2 isolates. These isolates represent all groups as determined in the latest phylogenetic analysis (Katsiani et al. 2015). However, other viruses were also present in these trees (data not shown).

Plant tissue sampling. Leaves and annual shoots from the eight infected sweet cherry trees were collected during the months they were available, as follows: three leaves (apical, middle, and basal positions) of a single tree were pooled in one sample, and an annual shoot located in the middle of the canopy, for a total of eight samples/month/tissue type. Blossoms were also collected in March.

Isolation of total RNA. Extraction of total RNA was performed from $200 \mathrm{mg}$ of the collected tissue according to method A of Chatzinasiou et al. (2010). RNA was eluted in $80 \mu \mathrm{l}$ of RNase-free water, quantified on a NanoDropND-100 spectrophotometer (NanoDrop Technologies), and stored at $-80^{\circ} \mathrm{C}$ until use.

Primers and TaqMan probe design for real-time RT-PCR. Sequences from all publicly available isolates were retrieved from GenBank and aligned using MEGA 5.1 (Tamura et al. 2011). The 3' terminus of the capsid protein (CP) gene was found to be more conserved than other areas of the genome, and primers LCh-A, LCh-B, and LCh-DF (sense) and LCh-C, LCh-D, and LCh-DR (antisense) were designed on this region (Table 1). The expected amplicon size for all primer sets was $134 \mathrm{bp}$. The TaqMan probe TCGAARGGA GCTCTYCATGTTTCGCA was labeled with 6-FAM dye and ZNA4-BHQ-1 (Metabion International), at the $5^{\prime}$ and $3^{\prime}$ ends, respectively.

TaqMan one-step RT-PCR assay. LChV1 real-time RT-PCR was performed in PCR plates using the Mx3005P QPCR System (Agilent Technologies). The analyses of fluorescence data were conducted using the thermocycler software (v.4.00).

Concentrations were optimized to yield the lowest threshold cycle $(\mathrm{Ct})$ and the highest reporter fluorescence (relative fluorescence units 
[RFU]). Each reaction ( $25-\mu l$ final volume) contained $2 \mu l$ of total RNA, $1 \times$ F-517 L Optimized Detergent-free DyNAzyme EXT Buffer $(50 \mathrm{mM}$ Tris- $\mathrm{HCl}, 1.5 \mathrm{mM} \mathrm{MgCl} 2$, and $15 \mathrm{mM}\left[\mathrm{NH}_{4}\right]_{2} \mathrm{SO}_{4}$ ) (Finnzymes, Thermo Fisher Scientific), $0.2 \mathrm{mM}$ each dNTP, $4 \mathrm{mM}$ dithiothreitol, $1 \mathrm{U}$ of Superscript III RNaseH-RT, $1.5 \mathrm{mM}$ additional $\mathrm{MgSO}_{4}$ (InvitrogenLife Technologies), 3 U of Hot Start Taq DNA polymerase (Qiagen), and the optimum primer and TaqMan probe concentrations (Table 1).

The cycling conditions consisted of $45^{\circ} \mathrm{C}$ for $30 \mathrm{~min}$, followed by $95^{\circ} \mathrm{C}$ for $15 \mathrm{~min}$ and 50 cycles in three steps: $30 \mathrm{~s}$ at $95^{\circ} \mathrm{C}, 15 \mathrm{~s}$ at $50^{\circ} \mathrm{C}$, and $45 \mathrm{~s}$ at $60^{\circ} \mathrm{C}$. Each run (plate) included three replicate reactions each for testing samples, positive controls, and nontemplate controls.

Standard curves generation. A portion of the LChV1 GR isolate (accession number HG792420), containing the $3^{\prime}$ CP domain, was amplified using primers CPF1 (5'-GTTATCCAAACGTACTGAGA G-3') and CPmR1 (5'-GGAAGGTAGGTTTCAAATTC-3') designed for the purposes of this study. The resulting amplicon was purified using the NucleoTrap Extraction II Kit (Macherey-Nagel), subsequently ligated into the pCR4-TOPO vector (Invitrogen-Life Technologies), and cloned into Escherichia coli. The presence of the fragment was confirmed by PCR and its orientation determined by sequencing. The recombinant plasmid was purified using the NucleoSpin Plasmid Kit (Macherey-Nagel), linearized using the restriction enzyme NotI-HF (New England Biolabs), and gel purified using the NucleoTrap Extract II Kit (Macherey-Nagel). RNA transcription was carried out with T3 RNA polymerase (Invitrogen-Life Technologies), followed by digestion of plasmid DNA with DNaseI (RNase-free; New England Biolabs). RNA transcripts were purified according to the RNA extraction method described by Chatzinasiou et al. (2010) and their concentration determined using a spectrophotometer (Biophotometer; Eppendorf). The molecular weight of the RNA transcripts was calculated by the available online Oligo Calc tool (http://biotools.nubic.northwestern.edu/ OligoCalc.html), and the Avogadro constant was used to estimate the number of copies of LChV1 RNA. Ten-fold serial dilutions $\left(10^{1}\right.$ to $10^{8}$ copies/ $\mu \mathrm{l}$ ) were prepared by mixing the RNA transcript with diethyl pyrocarbonate (DEPC)-treated water containing Carrier RNA (Qiagen) at $50 \mathrm{ng} / \mu \mathrm{l}$ and used to generate standard curves for the quantification of LChV1 populations in the testing samples. Each dilution was tested in triplicate.

Analytical and diagnostic sensitivity. The analytical sensitivity of the real-time RT-PCR was compared with a nested RT-PCR protocol (Katsiani et al. 2015). For that purpose, total RNA extracted from a plant infected with the virus was serially diluted (10-fold) in total RNA extracted from an LChV1-free plant after milling the samples with the Lysis buffer (Chatzinasiou et al. 2010). Each dilution $(2 \mu \mathrm{l})$ was then amplified in a $25-\mu \mathrm{l}$ RT-PCR followed by a nested PCR, as described before (Katsiani et al.2015). The onestep real-time RT-PCR was carried out using the same dilutions as the nested RT-PCR. Each dilution was tested in triplicate.

The presence of the virus was examined by real-time RT-PCR in 249 stone fruit trees ( 51 sweet cherry, 65 almond, 60 plum, 43 peach, and 30 apricot trees). Samples were collected from stone fruit orchards and were also tested by the nested RT-PCR method described above (Katsiani et al. 2015). Twenty-four samples were found positive for LChV1 and were used in the present study.

Absolute and relative quantification of the viral titer in sweet cherry cultivars. Absolute quantitation of LChV1 was performed using $2 \mu \mathrm{l}$ of total RNA extract from each sample that was tested in triplicate and the mean $\mathrm{Ct}$ value was estimated. The number of RNA molecules in each sample was calculated by interpolation of the mean $\mathrm{Ct}$ value to the standard curve equation.

At the same time, an internal control assay was developed to amplify mRNA of the translation elongation factor 2 (TEF 2) (reference gene) to allow for the normalization of the corresponding LChV1 values. In order to design primers and a Texas Red-labeled probe, a multiple alignment of the TEF 2 gene from all publicly available sequences was performed using MEGA 5.1 (Tamura et al. 2011). The selected primers TEF-F1 and TEF-R1 yielded an amplicon of $83 \mathrm{bp}$. The reaction mixture (excluding probe and primers) and the cycling conditions applied were as described previously for LChV1 real-time RT-PCR. Primers and TaqMan probe concentrations used are listed in Table 1. TEF primer efficiency $(E)$ was evaluated after serial 10-fold dilutions from LChV1-free sweet cherry total RNA extract ( 48.40 to $48.40 \times 10^{-8} \mathrm{ng}$ ) in DEPC-treated water containing Carrier RNA (Qiagen) at $50 \mathrm{ng} / \mu \mathrm{l}$. Prior to the dilutions, the RNA extract was treated with DNase I (RNase-free; New England Biolabs). In total, three replicates from each serial dilution were used to generate the standard curves.

Relative quantification was determined using $5 \mathrm{ng} / \mu \mathrm{l}$ from each total nucleic acid extract treated with DNase I (RNase-free; New England Biolabs). From the DNase-free samples, $10 \mathrm{ng}$ was added to the reaction mixture and the real-time RT-PCR for LChV1 and TEF 2 were applied. Each sample was tested in three replicates.

LChV1 titer within the plant. Efficiencies of LChV1 and TEF 2 amplifications were estimated from the standard curves by the equation $E=10^{(-1 / \text { slope) }}$ (Bustin 2000). As a percentage, it is expressed by the formula $\%=(E-1) \times 100$. From the real-time RT-PCR assays, Ct values for leaf and shoot samples were tabulated and averaged separately. The Pfaffl equation was used to calculate relative levels of the virus throughout the year for each tissue with the relative expression software tool (REST 2009; Qiagen) (Pfaffl 2001; Pfaffl et al. 2002): relative gene expression $(R)=\left(E_{\text {target }}\right)^{\Delta \mathrm{Ct} \text { target(control-treated) }} /\left(E_{\mathrm{ref}}\right)^{\Delta \mathrm{Ct} \text { ref(control-treated) }}$, where $\mathrm{Ct}$ is the PCR cycle number at which fluorescence crosses the threshold; $E_{\text {target }}$ and $E_{\text {ref }}$ are primer efficiencies for LChV1 and reference gene (TEF 2), respectively; $\Delta \mathrm{Ct}$ target control is the sample, one for each tissue (leaves and annual shoots), that exhibited the lowest viral titer $(\mathrm{Ct}>$ 34), whereas its Ct value for the TEF 2 gene did not differ from the mean value of all samples tested, minus the corresponding Ct value of every other sample obtained from the same tissue. Similarly, $\Delta \mathrm{Ct}$ ref was calculated by the $\mathrm{Ct}$ values of the TEF 2 gene for the control sample minus the subsequent $\mathrm{Ct}$ values of all other samples for each tissue.

Table 1. Little cherry virus 1 (LChV1), TEF 2 primers, and TaqMan probes used in the real time reverse-transcription polymerase chain reaction assays ${ }^{\mathrm{a}}$

\begin{tabular}{|c|c|c|c|c|}
\hline Primers, probe & Sequence $5^{\prime}-3^{\prime}$ & Position & Concentration $(\mu \mathrm{M})$ & Temperature $\left({ }^{\circ} \mathrm{C}\right)$ \\
\hline \multicolumn{5}{|l|}{ Forward primer } \\
\hline LCh-A & CCAATGCACAAAGCACATATGA & $1.068-1.089^{\mathrm{b}}$ & 0.25 & 62.6 \\
\hline LCh-B & CCAATGCATAAAGCTCATATGA & $1.068-1.089^{\mathrm{b}}$ & 0.25 & 59.8 \\
\hline LCh-DF & CCAATGCACAAAGCATCAATGA & $1.068-1.089^{b}$ & 0.25 & 63.1 \\
\hline TEF-F1 & CAGTGCCCTWTTGGAAATGATGA & $987-1009^{c}$ & 0.4 & $63-64$ \\
\hline \multicolumn{5}{|l|}{ Reverse primer } \\
\hline LCh-C & ACCGCGACGTGGTCCTAATA & $1.184-1.203^{\mathrm{b}}$ & 0.25 & 65.6 \\
\hline LCh-D & ACCTCGACGTGGTCCCAATA & $1.184-1.203^{\mathrm{b}}$ & 0.25 & 65.5 \\
\hline LCh-DR & ACCACGACGTGGTCCTAACA & $1.184-1.203^{\mathrm{b}}$ & 0.25 & 65.8 \\
\hline TEF-R1 & CCCTCGTACAAGTTCTCAACACG & $1.048-1.070^{\mathrm{c}}$ & 0.4 & 64 \\
\hline \multicolumn{5}{|l|}{ TaqMan probe } \\
\hline LCh-P3 & 6-FAM-TCGAARGGAGCTCTYCATGTTTCGCA-ZNA4-BHQ1 & $1.156-1.181^{\mathrm{b}}$ & 0.12 & $69-71$ \\
\hline TEF-P & TexasRed-TCACCTTCCCTCTCCTTCAACTGCCCAGAGA-BHQ2 & $1.014-1.044^{\mathrm{c}}$ & 0.1 & 72 \\
\hline
\end{tabular}

a $\mathrm{R}=\mathrm{A}-\mathrm{G}$ and $\mathrm{Y}=\mathrm{C}-\mathrm{T}$.

${ }^{\mathrm{b}}$ Position of hybridization of each primer from the start codon of the capsid protein gene of the LChV1 isolate V2356 (JX669615).

c Position of hybridization of each primer from the start codon of the TEF 2 gene (JQ732180). 
To define the most appropriate sampling period for LChV1, all $R$ (for relative quantification) and $\mathrm{Ct}$ (for absolute quantification) values obtained were analyzed by a Wilcoxon signed-rank nonparametric test (SPSS Inc.) to determine significant differences of virus concentrations between months. A test significance level of $P \leq 0.05$ calculated with the Monte-Carlo simulation was used (SPSS Inc.). $R$ and $\mathrm{Ct}$ maximum, minimum, and median values; $P$ value; and the standard deviation of the $\mathrm{Ct}$ were estimated with the SPSS v.13 software. The $R$ values were $\log _{10}$ transformed prior to analyses.

\section{Results}

TaqMan assay and standard curves. The presence of all three primer sets and the TaqMan probe in the same reaction mixture was essential for the successful detection of all isolates in the study. Attempts to replace the three primer pairs with a single pair of degenerate primers have led to lower efficiency of the assay. The combination of primers at $0.25 \mu \mathrm{M}$ each and probe at $0.12 \mu \mathrm{M}$ gave the lowest $\mathrm{Ct}$ and the highest RFU. No amplification was observed with either healthy plant control or nontemplate control, confirming the specificity of the assay.

The amplification efficiency was calculated at $96.7 \%\left(R^{2}=0.998\right)$ for the virus and $93.5 \%\left(R^{2}=0.994\right)$ for the internal control (Fig. 1). The detection threshold was $10^{2}$ copies of LChV1 RNA transcripts when diluted in DEPC water (Fig. 1A). Regression analysis of the LChV1 and TEF 2 standard curves demonstrated that the assays are highly efficient, indicating that they can be used to estimate LChV1-RNA concentration in infected material.

Sensitivity comparisons. The LChV1 isolate was consistently detected by nested RT-PCR when undiluted extract was used but detection was inconsistent with extracts diluted 1:10. The real-time RT-PCR Ct values were $<36$, even when extracts were diluted 1: 10.000 (Fig. 2).
Field screening. LChV1 was detected in all 24 samples found to be infected with the virus in previous tests using the nested RT-PCR ( 21 of 51 sweet cherry, 0 of 65 almond, 2 of 60 plum, 1 of 43 peach, and 0 of 30 apricot samples) (Katsiani et al. 2015). The virus was identified in an additional 37 samples with the real-time RT-PCR, which included 9 plum, 1 almond, and 27 sweet cherry. All 37 samples were tested with the real-time RT-PCR in three independent replicates in different runs, with no significant $\mathrm{Ct}$ value deviations observed, reinforcing the reproducibility of the real-time RT-PCR.

Detection in leaves, shoots, and blossoms. The detection of the virus and the TEF 2 gene was successful by the real-time RT-PCR assays in all tested leaf, shoot, and blossom samples. Based on the $\mathrm{Ct}$ values, a high fluctuation of the viral titer was observed in leaves and shoots whereas there were no significant differences in TEF 2 expression (Table 2). Ct values from leaves and shoots were used for the absolute and relative quantification of the virus throughout the year. Blossoms were not included in the seasonal fluctuation analysis, because they were available only in March.

Viral titer fluctuation. Virus titer in eight infected sweet cherry trees was examined. $\mathrm{Ct}$ values fluctuated among different isolates and, to avoid extreme values that could affect the average population titer, we calculated the median $\mathrm{Ct}$ value for each month. Based on the median value, the virus titer reached the detection threshold and up to $10^{7}$ RNA molecules throughout the year. Independent of the tissue, the minimum and the maximum virus population was approximately $3.00 \times 10^{5}$ and $4.35 \times 10^{7}$ RNA molecules, respectively (Supplementary Table $\mathrm{S} 1$ ).

In shoots, the virus titer was rather stable (ranging from $10^{6}$ up to $10^{7}$ RNA molecules), with the highest numbers observed in April, July, and November $\left(3.80 \times 10^{7}, 4.35 \times 10^{7}\right.$, and $3.87 \times 10^{7}$ RNA molecules, respectively). In leaves, the median virus titer increased from spring to June and reached the highest number in July
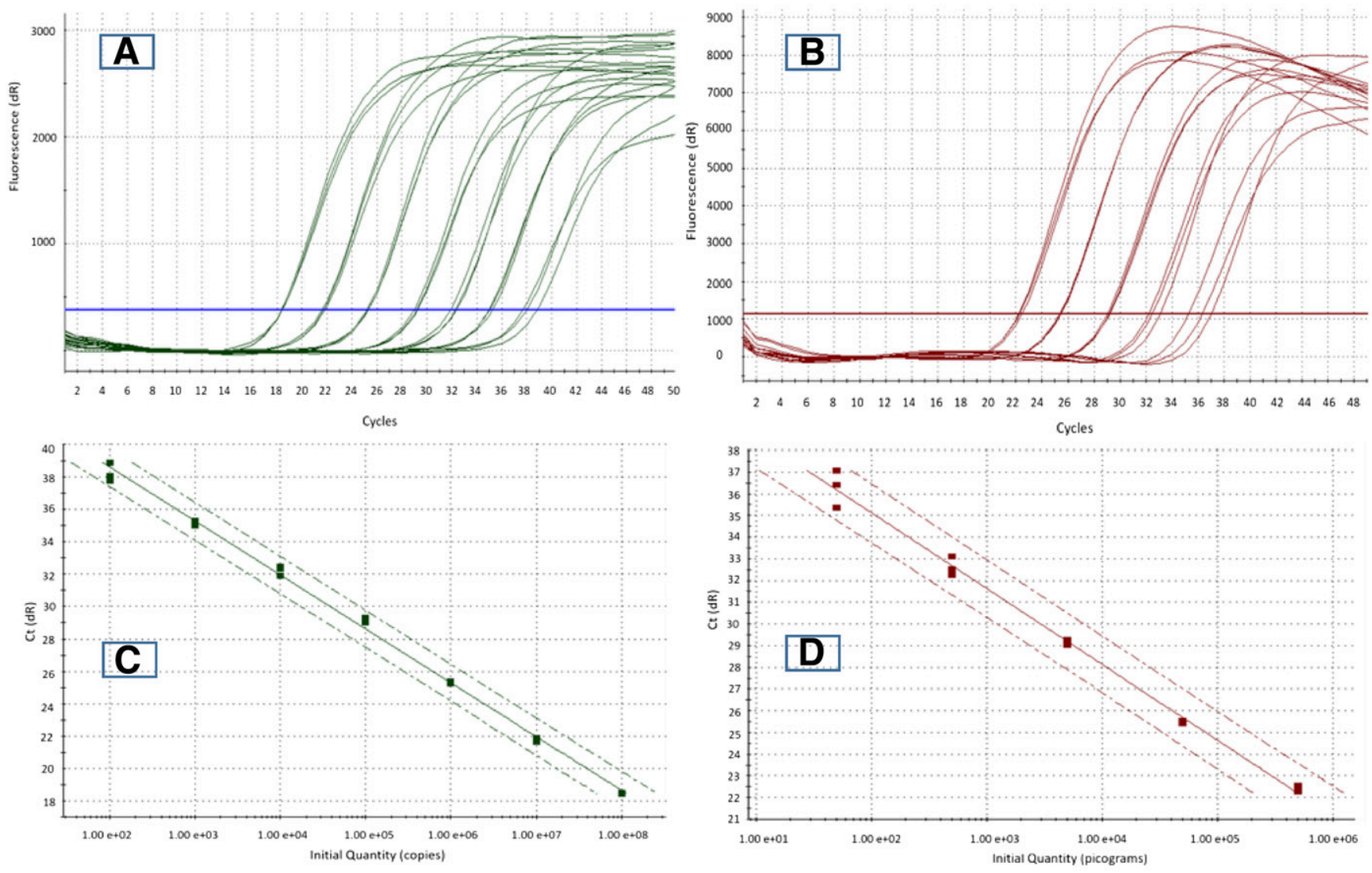

Fig. 1. Amplification plots of Little cherry virus 1 (LChV1) (six LChV1-specific primers were included in the reaction mixture) and TEF 2 detection. A, FAM fluorescent signals generated from a dilution series of LChV1-RNA transcripts. From left to right, the curves represent RNA 10 -fold serial dilutions, from $10^{8}$ to 100 copies per reaction, performed in three replicates. B, Texas-red fluorescent signals generated from a dilution series of TEF 2-RNA extract. From left to right, the curves represent RNA 10-fold serial dilutions, from 48.50 to $48.50 \times 10^{-4}$ ng per reaction, performed in three replicates. C, Corresponding standard curve for LChV1. D, Corresponding standard curve for TEF 2 . 
$\left(1.41 \times 10^{7}\right.$ RNA molecules $)$, decreasing to $3.70 \times 10^{5}$ RNA molecules in November.

Seasonal progress of the viral titer with relative quantification. The lowest viral titer was observed in December $(\mathrm{Ct}=35.8)$ and November $(\mathrm{Ct}=34.3)$ for the isolate PHLC17 2 in shoots and leaves, respectively; and these samples were selected to be used as the target control samples for the Pfaffl equation. The $R$ values obtained from the Pfaffl equation indicate a high fluctuation of virus titer among different isolates. Therefore, all $R$ values were $\log _{10}$ transformed and the median $\log R$ value for each month was calculated. These values were used for the construction of virus expression smoothing curves in shoots and leaves using the nonparametric local regression method (Loess) (Jacoby 2000). Based on the graph, there is a rapid increase of the viral titer in shoots early in the spring. The virus has its highest concentration in April whereas, in May, a decrease was observed (Fig. 3). The titer starts to increase again in June and July and remains rather stable from August to October. The lowest levels were observed during winter (December and February). In leaves, the viral titer was high early in the spring (April) and reached its highest value in July. In August, a rapid decrease was observed. Although followed by a small increase in the next 2 months, the titer never reached spring levels. October and November registered a decline in virus titer.

Optimal sampling period. In each plant tissue, months exhibiting the highest median viral titer were compared against all others with multiple tests of significance ( $P$ value). Based on the absolute quantification, shoots harbored the highest viral titer in April, July, and November. Among the three, the $\mathrm{Ct}$ value variation was minimal for April and, for that reason, it was selected to be tested against all others. In leaves, the highest titer was observed in July. Based on relative quantification, April and July had the highest titers in shoots and leaves, respectively (Fig. 3).

The titer in April was higher than in May, June, and December, whereas no significant differences were observed when compared with March, July, August, and November. These results were verified with both quantification methods (Table 3). However, some discrepancies were observed among April, September, October, and February. Based on the $\mathrm{Ct}$ values, the concentration of the virus in
April was higher than in September and October, whereas it did not differ significantly with February. In contrast, according to the $\log R$ values, the expression of the virus in April was higher than February whereas it did not differ significantly with September and October (Table 3). In leaves, the viral titer in July was higher than May, September, October, and November, with no significant differences observed in April and June for both quantification techniques.

\section{Discussion}

In the present study, a real-time RT-PCR assay was developed for the universal and accurate detection of LChV1. This method was used to monitor the viral titer in order to determine the most appropriate tissue and month for sampling. The $3^{\prime}$ end of the CP gene was found to be conserved among isolates and was selected as the target for detection. The presence of three primer pairs in the same reaction mixture was essential for the amplification of all isolates studied. The detection threshold was 100 copies, similar to realtime RT-PCR methods applied for the detection of other closteroviruses infecting woody plants such as Grapevine leafroll-associated virus 3 (GLRaV3), Grapevine leafroll-associated virus 2 (GLRaV2), and Citrus tristeza virus (CTV) (Beuve et al. 2007; Ruiz-Ruiz et al. 2007; Tsai et al. 2012).

Comparison tests of the present real-time RT-PCR against nested RT-PCR (Katsiani et al. 2015) demonstrated the higher sensitivity of

Table 2. Average threshold cycle $(\mathrm{Ct})$ values and standard deviation $( \pm$ standard deviation) from leaves, shoots, and blossoms of Little cherry virus 1 (LChV1) and TEF 2 when added in the real-time reverse-transcription polymerase chain reaction ${ }^{\mathrm{a}}$

\begin{tabular}{llcl}
\hline Plant tissue & LChV1 (AQ) & LChV1 (RQ) & TEF 2 (RQ) \\
\hline Leaves & $26.35 \pm 4.39$ & $27.78 \pm 3.98$ & $25.54 \pm 1.29$ \\
Shoots & $23.03 \pm 3.49$ & $26.13 \pm 3.05$ & $26.19 \pm 0.76$ \\
Blossom & $23.9 \pm 1.9$ & $29.56 \pm 0.71$ & $26.3 \pm 0.76$ \\
\hline
\end{tabular}

${ }^{a}$ In total, $2 \mu 1$ of total RNA extract for absolute quantification (AQ) and $10 \mathrm{ng}$ of total RNA extract for relative quantification (RQ) was added. The average $\mathrm{Ct}$ for each tissue was calculated using the $\mathrm{Ct}$ obtained for all months from all eight trees.
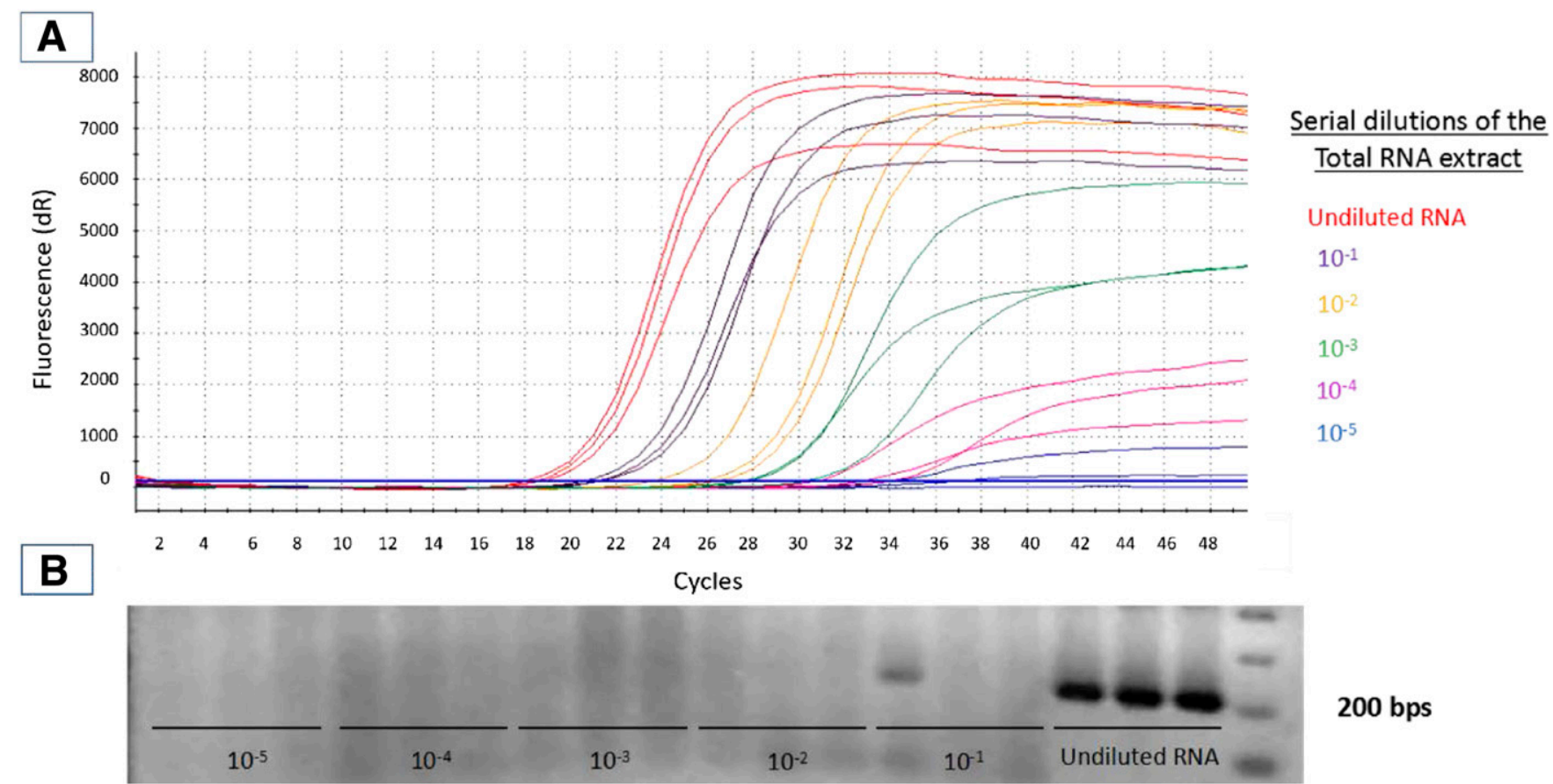

200 bps

Fig. 2. Dilution end point comparison between conventional nested reverse-transcription polymerase chain reaction (RT-PCR) and real-time RT-PCR for the detection of Little cherry virus 1 (LChV1) using three replications of dilution series ranging from 1 to $10^{-5}$. A, Plot of RNA dilution series (x-axis) against the threshold cycle values ( $y$-axis) of the real-time RT-PCR (six LChV1-specific primers were included in the reaction mixture). B, Agarose gel electrophoresis profile of the amplification products obtained by conventional nested RT-PCR (Katsiani et al. 2015). 
the former. Because most infected samples detected by real-time RTPCR yielded $\mathrm{Ct}$ value ranges of between 22 and 25, the failure of the conventional nested RT-PCR to detect the virus in such samples has two plausible explanations: the higher genetic diversity of the nested RT-PCR target (HSP70h gene) could lead to primer mismatching, and the higher abundance of the real-time RT-PCR target (CP gene) in the form of genomic and subgenomic RNA could lead to higher product yield. The infection rate in plum in Greece was found to be higher (18.3\%) than previously assessed (Katsiani et al. 2015), whereas LChV1 was prevalent in sweet cherry $(94 \%)$. Most of the sweet cherry samples tested were collected from plants with no obvious little cherry disease (LChD) symptoms (Katsiani et al. 2015), further enhancing the hypothesis that LChV1 might not be directly involved in $\mathrm{LChD}$ development. The virus was detected for the first time in an almond tree in Greece. However, more studies are needed in order to verify almond as a host of LChV1 in Greek stone fruit orchards.

In recent years, absolute and relative quantifications have been used extensively because they can easily estimate the abundance of an organism of interest. Therefore, both quantification methods were used in the present study in order to verify our results. The titer of LChV1 was calculated in leaves and shoots from eight sweet cherry trees for a year. LChV1 isolates were selected on the basis of a recent phylogenetic analysis where four discrete groups were formed (Katsiani et al. 2015), all of which were included in our study. For the simultaneous detection of the TEF 2 gene, a real-time RT-PCR was developed and applied in parallel with the real-time RT-PCR for LChV1. The obtained data were used for the normalization of viral titer and the evaluation of the quality of the total RNA extract used for preventing false-negative results or inappropriate $\mathrm{Ct}$ values due to poor quality of the extract (Pfaffl 2001; Pfaffl et al. 2002). The application of real-time RT-PCR has shown that the expression of TEF 2 was rather stable in both tissues throughout the year, though the viral titer varied significantly.

According to the number of the RNA molecules and the relative expression estimations, the fluctuation of the virus varied among different isolates as well as within each isolate throughout the year. However, the reason of this deviation is yet to be determined. It is known that, in mixed viral infections, interactions such as synergism or antagonism may occur (Moreno et al. 2008; Rubio et al. 2013). Because all eight trees tested were coinfected with other cherry viruses, it is possible that the observed deviation is an outcome of the presence of other viruses (data not shown). Moreover, potential interactions between the isolates and the cultivars or the climatic conditions during seasons cannot be excluded.

Based on both quantification methods, the concentration of the virus was found to be higher in shoots than in leaves. This is not unexpected for closteroviruses, because they show tissue-specific tropism and, for most of them, replication is limited to the phloem (Bar-Joseph et al. 1979). The virus titer in shoots increases rapidly early in the spring, followed by a sudden drop in May, and returns to its high levels during summer, where it stays rather stable until October. The viral titer remained stable during winter months. The relative titer of the virus decreases during this period. This discrepancy between the absolute and relative quantification during the dormant phase might be derived from small changes in the reference gene expression occurring during these months. However, more tests are needed in order to confirm this hypothesis.

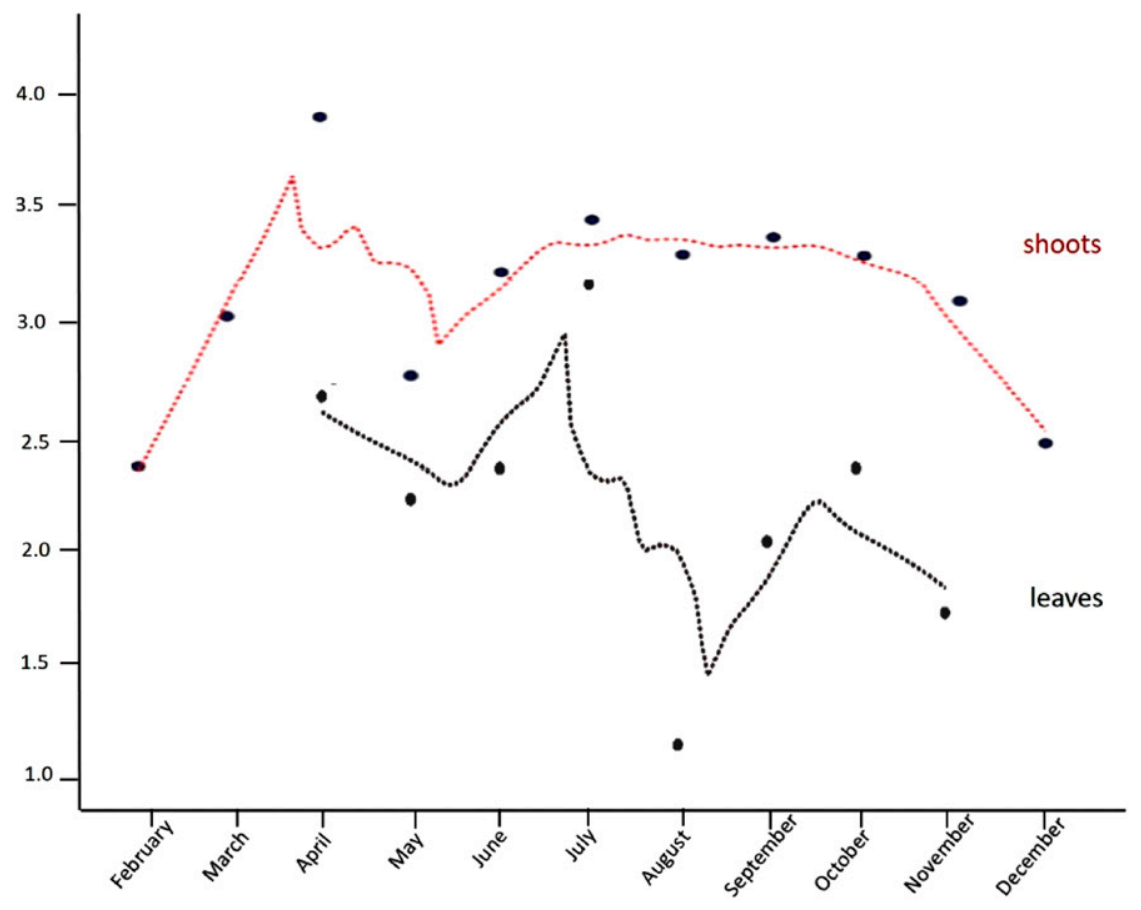

Fig. 3. Loess curve fitted to data on expression of Little cherry virus 1 (LChV1) in shoots and leaves throughout the year: $y$-axis $=$ median log $_{10}$-transformed relative expression of LChV1 and $\mathrm{x}$-axis $=$ months studied (maximum and minimum logR values are given in Supplementary Table S2).

Table 3. Nonparametric Wilcoxon signed-rank test comparison tests of the threshold cycle values (obtained from the absolute quantification [AQ]) and the log $10^{-}$ transformed $R$ values (obtained from the relative quantification [RQ]) of April for shoots and July for leaves against all other months ${ }^{\mathrm{a}}$

\begin{tabular}{|c|c|c|c|c|c|c|c|c|c|c|c|c|c|c|c|c|c|c|c|c|c|c|}
\hline \multirow[b]{2}{*}{ Method (month) } & \multicolumn{2}{|c|}{ February } & \multicolumn{2}{|c|}{ March } & \multicolumn{2}{|c|}{ April } & \multicolumn{2}{|c|}{ May } & \multicolumn{2}{|c|}{ June } & \multicolumn{2}{|c|}{ July } & \multicolumn{2}{|c|}{ August } & \multicolumn{2}{|c|}{ September } & \multicolumn{2}{|c|}{ October } & \multicolumn{2}{|c|}{ November } & \multicolumn{2}{|c|}{ December } \\
\hline & $\mathbf{A Q}$ & $\mathbf{R Q}$ & $\mathbf{A Q}$ & $\mathbf{R Q}$ & AQ & $\mathbf{R Q}$ & $\mathbf{A Q}$ & $\mathbf{R Q}$ & $\mathbf{A Q}$ & RQ & AQ & $\mathbf{R Q}$ & $\mathbf{A Q}$ & $\mathbf{R Q}$ & $\mathbf{A Q}$ & $\mathbf{R Q}$ & AQ & $\mathbf{R Q}$ & $\mathbf{A Q}$ & $\mathbf{R Q}$ & $\mathbf{A Q}$ & $\mathbf{R Q}$ \\
\hline Shoo & 0.14 & 0.04 & 0.34 & 0.08 & & . & 0.04 & 0.01 & 0.02 & 0.04 & 0.41 & 0.11 & 0.16 & 0.16 & 0.01 & 0.16 & 0.04 & 0.06 & 0.29 & 0.06 & 0.05 & 0.02 \\
\hline Leaves (July) & $\ldots$ & $\ldots$ & $\ldots$ & $\ldots$ & 0.06 & 0.23 & 0.03 & 0.01 & 0.08 & 0.13 & $\ldots$ & $\ldots$ & 0.06 & 0.01 & 0.03 & 0.01 & 0.01 & 0.04 & 0.01 & 0.04 & $\ldots$ & .. \\
\hline
\end{tabular}

${ }^{a} P \leq 0.05$ are statistically significant and are represented in bold. 
Viral fluctuation in leaves was higher than in shoots. The titer in leaves gradually increased during the spring and reached its highest values in July, dropping to lower levels in all other months. This might be due to the source-to-sink model of virus movement (Hipper et al. 2013). The transition of leaves from a sink to a source status during their maturation could explain the lower virus titer observed late in the growing season. Climatic conditions, especially temperature, can also affect the replication and accumulation of viruses (Constable et al. 2013; Glasa et al. 2003), mainly through the differential induction of RNA silencing (Siddiqui et al. 2008). Therefore, the high temperatures recorded in August could have resulted in the reduction of virus accumulation, leading to a decrease in the viral titer during this month. Similar studies on the seasonal fluctuation of GLRaV3, an ampelovirus infecting grapevines, have shown that the highest viral titer was observed during summer (June on basal and middle petioles and July on apical petioles). In accordance with our observations, the GLRaV3 population also decreased after these months and remained at lower levels (Tsai et al. 2012).

In conclusion, the real-time RT-PCR developed herein is a highly sensitive tool and can be applied for the accurate detection of LChV1, providing quick and reliable results. The virus can be easily detected in all aerial tissues throughout the year but we recommend sampling from shoots during early spring and late summer and from leaves in April as well as early summer. The new real-time RT-PCR described in this study opens new possibilities for the control of LChV1 and could be applied in sanitary selection protocols, certification schemes, or eradication programs.

\section{Acknowledgments}

We thank B. Komorowska (Instytut Sadownictwa I Kwiaciarstwa im. Szczepana Pieniazka, Poland), A. Minafra (Consiglio Nazionale Delle Ricerche, Centro di studio sui virus e le virosi delle colture Mediterranee, Dipartimento di protezione delle piante, Universita degli Studi di Bari, Italy), M. Bernardy (Pacific Agri-Food Research Centre, Agriculture and Agri-Food Canada, Canada), and G. Adam (University of Hamburg, Germany) for providing the LChV1 isolates; G. Menexes (School of Agriculture, Aristotle University of Thessaloniki) for his help on the statistical analysis; and I. E. Tzanetakis (Department of Plant Pathology, University of Arkansas System) for critical reading of the manuscript.

\section{Literature Cited}

Barba, M., Ilardi, V., and Pasquini, G. 2015. Control of pome and stone fruit virus diseases. Adv. Virus Res. 91:47-83.

Bar-Joseph, M., Garnsey, S. M., and Gonsalves, D. 1979. The closteroviruses: A distinct group of elongated plant viruses. Adv. Virus Res. 25:93-168.

Beuve, M., Sempe, L., and Lemaire, O. 2007. A sensitive one-step real-time RTPCR method for detecting Grapevine leafroll-associated virus 2 variants in grapevine. J. Virol. Methods 141:117-124.

Bustin, S. A. 2000. Absolute quantification of mRNA using real-time reverse transcription polymerase chain reaction assays. J. Mol. Endocrinol. 25:169-193.

Candresse, T., Marais, A., Faure, C., and Gentit, P. 2013. Association of Little cherry virus 1 (LChV1) with the Shirofugen stunt disease and characterization of the genome of a divergent LChV1 isolate. Phytopathology 103:293-298.
Chatzinasiou, E., Dovas, C. I., Papanastassopoulou, M., Georgiadis, M., Psychas, V., Bouzalas, I., Koumbati, M., Koptopoulos, G., and Papadopoulos, O. 2010. Assessment of bluetongue viraemia in sheep by real-time PCR and correlation with viral infectivity. J. Virol. Methods 169:305-315.

Constable, F. E., Connellan, J., Nicholas, P., and Rodoni, B. C. 2013. The reliability of woody indexing for detection of grapevine virus-associated diseases in three different climatic conditions in Australia. Aust. J. Grape Wine Res. 19:74-80.

Glasa, M., Labonne, G., and Quiot, J. B. 2003. Effect of temperature on plum pox virus infection. Acta Virol. 47:49-52.

Hipper, C., Brault, V., Ziegler-Graff, V., and Revers, F. 2013. Viral and cellular factors involved in phloem transport of plant viruses. Front. Plant Sci. 4:1-24.

Jacoby, W. G. 2000. Loess: A nonparametric, graphical tool depicting relationships between variables. Elect. Stud. 19:577-613.

Jelkmann, W., and Eastwell, K. C. 2011. Little cherry virus 1 and 2. Pages 153-160 in: Virus and Virus-Like Diseases of Pome and Stone Fruits. A. Hadidi, M. Barba, T. Candresse, and W. Jelkmann, eds. American Phytopathological Society, St. Paul, MN.

Jelkmann, W., Leible, S., and Rott, M. 2008. Little Cherry Closteroviruses 1 and 2, their genetic variability and detection by real-time-PCR. Acta Hortic. 781: 321-330.

Katsiani, A. T., Maliogka, V. I., Amoutzias, G. D., Efthimiou, K. E., and Katis, N. I. 2015. Insights into the genetic diversity and evolution of Little cherry virus 1. Plant Pathol. 64:817-824.

Lim, S., Igori, D., Yoo, R. H., Zhao, F., Cho, I. S., Choi, G. S., Lim, H. S., Lee, S. H., and Moon, J. S. 2015. Genomic detection and characterization of a Korean isolate of Little cherry virus 1 sampled from a peach tree. Virus Genes 51:260-266.

Matic, S., Minafra, A., Sanchez-Navarro, J. A., Pallas, V., Myrta, A., and Martelli, G. P. 2009. 'Kwanzan Stunting' syndrome: Detection and molecular characterization of an Italian isolate of Little cherry virus 1. Virus Res. 143:61-67.

Moreno, P., Ambros, S., Albiach-Marti, M. R., Guerri, J., and Pena, L. 2008. Citrus tristeza virus: A pathogen that changed the course of the citrus industry. Mol. Plant Pathol. 9:251-268.

Pfaffl, M. W. 2001. A new mathematical model for relative quantification in realtime RT-PCR. Nucleic Acids Res. 29:e45.

Pfaffl, M. W., Horgan, G. W., and Dempfle, L. 2002. Relative expression software tool (REST@) for group-wise comparison and statistical analysis of relative expression results in real-time PCR. Nucleic Acids Res. 30:e36.

Rubio, L., Guerri, J., and Moreno, P. 2013. Genetic variability and evolutionary dynamics of viruses of the family Closteroviridae. Front. Microbiol. 4:151.

Ruiz-García, A. B., Martínez, C., Santiago, R., García, M. T., de Prado, N., and Olmos, A. 2016. First report of Little cherry virus 1 (LChV1) in sweet cherry in Spain. Plant Dis. 100:2340.

Ruiz-Ruiz, S., Moreno, P., Guerri, J., and Ambrós, S. 2007. A real-time RT-PCR assay for detection and absolute quantitation of Citrus tristeza virus in different plant tissues. J. Virol. Methods 145:96-105.

Siddiqui, S. A., Sarmiento, C., Kiisma, M., Koivumäki, S., Lemmetty, A., Truve, E., and Lehto, K. 2008. Effects of viral silencing suppressors on tobacco ringspot virus infection in two Nicotiana species. J. Gen. Virol. 89:1502-1508.

Tamura, K., Peterson, D., Peterson, N., Stecher, G., Nei, M., and Kumar, S. 2011. MEGA5: Molecular evolutionary genetics analysis using maximum likelihood, evolutionary distance and maximum parsimony methods. Mol. Biol. Evol. 28: 2731-2739.

Tsai, C. W., Daugherty, M. P., and Almeida, R. P. P. 2012. Seasonal dynamics and virus translocation of Grapevine leafroll-associated virus 3 in grapevine cultivars. Plant Pathol. 61:977-985.

Wang, J., Zhu, D., Tan, Y., Zong, X., Wei, H., Hammond, R. W., and Liu, Q. 2016. Complete nucleotide sequence of Little cherry virus 1 (LChV1) infecting sweet cherry in China. Arch. Virol. 161:749-753. 